\title{
Fettvev i testiklene
}

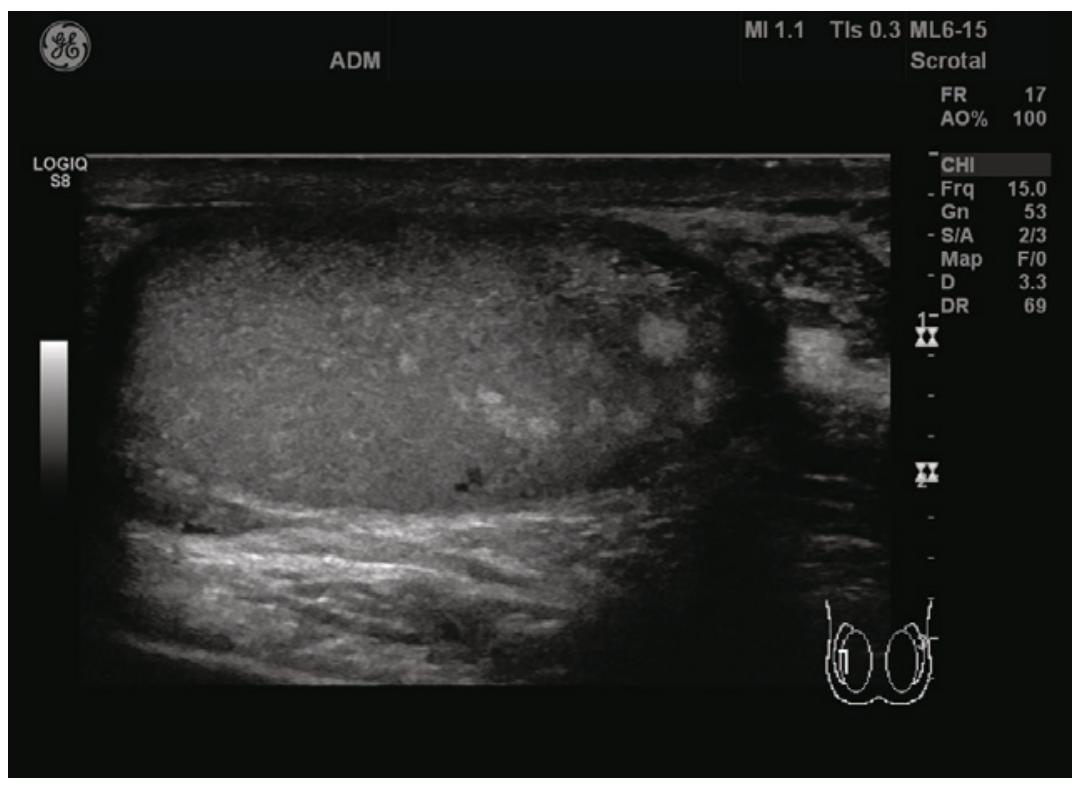

En frisk mann i 40-årene hadde spontane smerter i begge lyskeregioner og testikler og ble derfor henvist til ultralyd av fastlegen. Undersøkelsen viste tallrike, høyekkogene foci spredt i testiklene. Disse var diffust avgrenset, ikke skyggegivende og det ble ikke påvist dopplersignal. Lesjonene varierte $i$ størrelse opptil ca. $5 \mathrm{~mm}$. For øvrig var testiklene symmetriske og normalt store, hadde homogent ekko og sidelikt dopplersignal. Det var en $2 \mathrm{~mm}$ cyste i caput epididymis på venstre side, ellers ingenting å bemerke ved epididymis. Ingen tilleggsfunn. Se video fra undersøkelsen på internett. Bildet viser lesjoner med utseende som fettvev i testiklene, testikulær lipomatose. Dette må ikke forveksles med mikroforkalkninger som er vanligere og som regel ufarlig, men med en uavklart sammenheng med senere testikkelkreft (1).

Testikulær lipomatose er et patognomonisk funn som kan relateres til Cowdens syndrom, en sjelden, arvelig tilstand som er assosiert med økt risiko for utvikling av flere typer kreft $(2,3)$. På bakgrunn av dette funnet ble derfor pasienten henvist til utredning ved Seksjon for arvelig kreft, Oslo universitetssykehus. Andre differensialdiagnoser ved bilaterale, multifokale intratestikulære lesjoner er bl.a. germinalcelletumorer, leukemi, lymfom, metastaser, granulomatøs sykdom (sarkoidose, tuberkulose) og leydigcellehyperplasi (3).

Cowdens syndrom (multiple hamartoma syndrome) er en autosomalt dominant lidelse forårsaket av mutasjon i genet PTEN på kromosom 10 (2). Dette tumorsuppressorgenet har en sentral rolle ved kontroll av celleproliferasjon, differensiering og apoptose, og en mutasjon bidrar til økt cellulær proliferasjon i ektoderm, mesoderm og entoderm. Syndromet er assosiert med tallrike, benigne hamartomer i hud og på slimhinner. Benigne lesjoner kan ses i thyreoidea og tarm. Denne pasientgruppen har også forhøyet kreftrisiko for bl.a. bryst-, thyreoidea-, livmor- og nyrekreft. Nesten alle med dette syndromet har hodeomkrets over 97,5-prosentilen.

Den aktuelle pasienten har et stort hode og har hatt vanskeligheter med å finne passende hodeplagg hele livet. Som barn fikk han fjernet en stor «fettkul» under armen. I etterkant av ultralydundersøkelsen har han fått påvist en feil i $P T E N$-genet c.675T $>\mathrm{G}$, og grunnet funn av multiple, uspesifikke knuter i thyreoidea har han gjennomgått profylaktisk total tyreoidektomi.

Ved Seksjon for arvelig kreft ved Oslo universitetssykehus er det registrert $i$ alt 37 personer med Cowdens syndrom, hvorav to med testikulær lipomatose. Det finnes også enkelte tilfeller som er registrert ved andre sykehus. Testikulær lipomatose er et uvanlig funn på ultralyd som kan feiltolkes som mikroforkalkninger. Ved dette funnet bør pasienten henvises til genetisk utredning med tanke på Cowdens syndrom.

Pasienten har gitt samtykke til at artikkelen blir publisert.

\section{Billy Roger Parimalasingham}

billyrogerp@hotmail.com

Unni Bergan

Radiologisk avdeling

Ålesund sykehus
Kjersti Jørgensen

Seksjon for arvelig kreft Oslo universitetssykehus

Billy Roger Parimalasingham (f. 1982) er lege i spesialisering i radiologi og styremedlem i Norsk radiologisk forening.

Forfatter har fylt ut ICMJE-skjemaet og oppgir ingen interessekonflikter.

Unni Bergan (f. 1960) er spesialist i radiologi, overlege og sitter i styret for Norsk forening for abdominal radiologi.

Forfatter har fylt ut ICMJE-skjemaet og oppgir ingen interessekonflikter.

Kjersti Jørgensen (f.1972) er ph.d. og genetisk veileder.

Forfatter har fylt ut ICMJE-skjemaet og oppgir ingen interessekonflikter.

\section{Litteratur}

1. Kim W, Rosen MA, Langer JE et al. US MR imaging correlation in pathologic conditions of the scrotum. Radiographics 2007; 27: 1239-53.

2. Woodhouse JB, Delahunt B, English SF et al. Testicular lipomatosis in Cowden's syndrome. Mod Pathol 2005; 18: 1151-6.

3. Venkatanarasimha N, Hilmy S, Freeman S. Case 175: Testicular lipomatosis in Cowden disease. Radiology 2011; 261: 654-8.

Mottatt 17.10. 2014, første revisjon innsendt 9.12. 2014, godkjent 22.12. 2014. Redaktør: Lise Mørkved Helsingen. 